\title{
Ruminal protein degradability of a range of tropical pastures
}

\author{
M. K. Bowen ${ }^{\mathrm{A}, \mathrm{C}, \mathrm{D}}$, D. P. Poppi ${ }^{\mathrm{A}}$ and S. R. McLennan ${ }^{\mathrm{B}}$ \\ ${ }^{\text {A }}$ Schools of Animal Studies and Veterinary Science, University of Queensland, St Lucia, Qld 4072, Australia. \\ ${ }^{B}$ Department of Primary Industries and Fisheries, Locked Mail Bag 4, Moorooka, Qld 4105, Australia. \\ CPresent address: Department of Primary Industries and Fisheries, PO Box 6014, CQMC Rockhampton, QId 4702, \\ Australia. \\ ${ }^{D}$ Corresponding author. Email: maree.bowen@dpi.qld.gov.au
}

\begin{abstract}
The rumen degradability parameters of the diet selected by two to four oesophageal-fistulated Brahman steers grazing a range of tropical pastures were determined by incubation of extrusa in nylon bags suspended in the rumen of rumen-fistulated (RF) Brahman steers. The effective protein degradability (Edg) was determined by measuring the rate of disappearance of neutral detergent insoluble nitrogen (NDIN) less acid detergent insoluble nitrogen (ADIN) in the incubated extrusa. Six to eight RF steers also grazed each of the pastures along with the oesophageal-fistulated steers, to allow determination of key rumen parameters and rumen particulate matter fractional outflow rates (FOR). The seven pastures studied included: native tropical grass $\left(\mathrm{C}_{4}\right)$ pasture (major species Heteropogon contortus and Bothriochloa bladhii), studied in the early wet (NPEW), the wet/dry transition (NPT) and the dry (NPD) seasons; introduced tropical grass $\left(\mathrm{C}_{4}\right)$ pasture (Bothriochloa insculpta), studied in the mid wet season (BB); the introduced tropical legumes $\left(\mathrm{C}_{3}\right)$, Lablab purpureus (LL) and Clitoria ternatea $(\mathrm{BP})$; and the temperate grass $\left(\mathrm{C}_{3}\right)$ pasture, ryegrass (Lolium multiflorum, $\left.\mathrm{RG}\right)$. Using the measured particle FOR values in calculations, the Edg estimates were very high for both $\mathrm{C}_{4}$ and $\mathrm{C}_{3}$ species: $0.82-0.91$ and $0.95-0.98 \mathrm{~g} / \mathrm{g}$ crude protein $(\mathrm{CP})$, respectively. Substitution of an assumed FOR $\left(k_{p}=0.02 / \mathrm{h}\right)$ for the measured values for each pasture type did not markedly affect estimates of Edg. However, $\mathrm{C}_{4}$ tropical grasses had much lower effective rumen degradable protein (ERDP) fractions (23-66 g/ kg DM) than the $\mathrm{C}_{3}$ pasture species RG and LL (356 and $243 \mathrm{~g} / \mathrm{kg}$ DM, respectively). This was associated with a lower potential degradability and degradation rate of organic matter (OM) in sacco, lower in vitro organic matter digestibility (IVOMD) and CP concentrations in the extrusa, and lower ammonia-N and branched-chain fatty acid concentrations in rumen fluid for the tropical grasses. As tropical grass pastures senesced, there was a decline in Edg, the ERDP and rumen undegradable protein (UDP) fractions, the potential degradability and degradation rate of OM and the IVOMD. These results provide useful data for estimating protein supply to cattle grazing tropical pastures.
\end{abstract}

\section{Introduction}

Animal performance on tropical forages is determined by the rate and extent of digestion of the organic matter $(\mathrm{OM})$ in the rumen and by the concentration and effective degradability of the protein fraction (Edg). Accurate estimates of Edg are required to enable reliable predictions of microbial protein synthesis and protein flow to animal tissues. However, estimation of Edg in vivo is tedious and difficult and the widely used in sacco technique has been problematic due to the error caused by microbial colonisation of incubated samples and the difficulty in correcting for this (CSIRO 2007). Furthermore, in calculating Edg, an assumption has to be made on the fractional outflow rate (FOR) of material from the rumen, but this is difficult with grazing animals and there is limited data from ruminants grazing tropical pastures by which to assess this (CSIRO 2007). Previous work in pens has shown low degradation rates and extent of digestion of tropical grass hays (Hunter and Siebert 1985; Panjaitan et al. 2006). However, values obtained for mature hays may not be representative of the material selected by cattle grazing tropical pastures, which are characteristically heterogeneous in terms of both species composition and plant morphology (Stobbs 1975). The objective of this experiment was to determine Edg in the diet of steers grazing a range of tropical grasses and legumes.

\section{Materials and methods}

Pastures, animals and experimental procedures

Seven pasture types were studied over a 13-month period at Brian Pastures Research Station, near Gayndah, in south-east Queensland. These included:

(i) native tropical grass $\left(\mathrm{C}_{4}\right)$ pasture, with major species black speargrass (Heteropogon contortus) and forest bluegrass (Bothriochloa bladhii), grazed in the early wet season (NPEW);

(ii) native tropical grass $\left(\mathrm{C}_{4}\right)$ pasture, with major species black speargrass (Heteropogon contortus) and forest bluegrass (Bothriochloa bladhii), grazed in the wet/dry transition period (NPT);

(iii) native tropical grass $\left(\mathrm{C}_{4}\right)$ pasture, with major species black speargrass (Heteropogon contortus) and forest bluegrass (Bothriochloa bladhii), grazed in the dry season (NPD);

(iv) introduced tropical grass $\left(\mathrm{C}_{4}\right)$ pasture, creeping bluegrass (Bothriochloa insculpta), grazed in the mid wet season (BB); 
(v) introduced tropical legume $\left(\mathrm{C}_{3}\right)$ Dolichos lablab (Lablab purpureus cv. Highworth) (LL);

(vi) introduced tropical legume $\left(\mathrm{C}_{3}\right)$ butterfly pea (Clitoria ternatea cv. Milgarra) (BP); and

(vii) temperate grass $\left(\mathrm{C}_{3}\right)$ pasture, ryegrass (Lolium multiflorum cv. Tetila) which was included as a positive, temperate control (RG).

Six to eight rumen-fistulated (RF) Brahman (>75\% $B$. indicus) steers (initially 15 months old, $329 \pm 10.8 \mathrm{~kg}$ liveweight) grazed each pasture for at least 2 weeks of preliminary grazing, followed by 1 week of sampling. Rumen fluid samples were collected over the first 5 days of each sampling period, with the times of sampling $(0130,0400$, $0630,0800,1030,1300,1530,1800,2030$ and 2300 hours) randomly allocated between days. On any one day, the two sampling times were separated by at least $9 \mathrm{~h}$. Rumen fluid was collected from at least three different sites in the rumen of each steer. Subsamples of rumen fluid were bulked over the 10 sampling times for each steer and were frozen before analysis for volatile fatty acid (VFA) concentrations. Subsamples were kept for analysis for ammonia-nitrogen $(\mathrm{N})$ on 6 of the 10 sampling times $(0400,0800,1300,1530,1800$ and 2300 hours). These were acidified to $\mathrm{pH} \leq 3$ by adding concentrated sulfuric acid before storage at $-18^{\circ} \mathrm{C}$.

Twenty grams of $\mathrm{Yb}$-marked hay [oven-dried, 3-mm ground, Rhodes grass (Chloris gayana)] was dosed directly into the rumen twice daily at 0730 hours and 1630 hours, for the 5 days preceding the start of the sampling period and for the first 5 days of sampling. The $\mathrm{Yb}$ concentration was varied for each experiment so that the dose rate would approximate $55 \mathrm{mg} \mathrm{Yb} / \mathrm{kg}$ estimated dry matter intake of the RF steers. On day 6 of sampling, a final $\mathrm{Yb}$ dose was delivered into the rumen of each RF steer at 0900 hours, following the morning grazing period. Rumen digesta samples were collected for $\mathrm{Yb}$ analysis at times $4,8,12,25,36$ and $48 \mathrm{~h}$ after final $\mathrm{Yb}$ marker dosing. Digesta samples were collected from three different sites within the rumen on each occasion and bulked for analysis.

After a minimum of 6 days preliminary grazing on the treatment paddock, extrusa samples were collected from two to four oesophageal fistulated, Brahman ( $>75 \%$ B. indicus) steers (initially 5 years old, $599 \pm 27.3 \mathrm{~kg}$ liveweight) at least twice, often on consecutive days, during the period when RF steers were sampled. Oesophageal fistulated steers were held in yards off pasture overnight, before sampling at 0800 hours the following morning. The steers were allowed to graze the test pasture for $\sim 30$ min, or until the collection bags were filled. Extrusa samples were mixed thoroughly, then placed directly onto dry ice and later frozen. Subsamples were freeze-dried before analysis and incubation in nylon bags.

At the completion of the grazing studies, a representative bulk extrusa sample (3-mm ground) from each of the seven pasture types was incubated in nylon bags (Allied Filter Fabrics; monofilament polyester, $24 \times 10 \mathrm{~cm}$ outer dimension, pore size $45 \mu \mathrm{m})$ in the rumen of each of three RF steers. The samples were incubated in duplicate in each steer for each of 10 incubation times $(3,5,8,11,13,16,24,48,72$ and $96 \mathrm{~h})$. In addition, four control bags for each pasture type were washed and processed without being incubated. During nylon bag incubations, the RF steers were fed twice daily (0730 and
1530 hours, in equal portions) a standard diet consisting of lucerne (Medicago sativa) and Rhodes grass (Chloris gayana) hays ( $3: 5, \mathrm{w} / \mathrm{w}$, as fed), fed at $90 \%$ of ad libitum intake plus $1 \mathrm{~kg}$ /day of cottonseed meal. Filled bags were attached to a length of chain and then soaked in water for 5-10 min before being immersed in the rumen of the steers. Upon removal of bags from the rumen, digesta adhering to the bags was rinsed off and the bags were immediately frozen. Once all bags had been removed, the frozen bags were defrosted by placing them in cool water. The bags were then squeezed 10 times by hand under running tap water, before being rinsed on a set cycle in an automatic washing machine and then dried to determine proportional dry matter (DM) loss. After weighing, the residue from the nylon bags was bulked across all steers and replicates for each incubation time. Each bulk sample was analysed for OM content, while samples from the 5,8,11, 13 and $16 \mathrm{~h}$ incubations were analysed for neutral detergent insoluble nitrogen (NDIN) and acid detergent insoluble nitrogen (ADIN) concentrations. A representative subsample of the unincubated residue for each pasture type was also analysed for NDIN and ADIN concentrations.

\section{Analytical procedures}

DM content of samples was determined by drying to a constant weight in a forced draught oven at $60-70^{\circ} \mathrm{C}$. Samples were milled to $<1 \mathrm{~mm}$ before chemical analysis. The ash content was determined by heating dry samples in an electric muffle furnace (Thermogravimetric analyser TGA-601, LECO Corporation: St Joseph, MI) at $610^{\circ} \mathrm{C}$ to constant weight under an atmosphere of oxygen. Extrusa samples were analysed for total $\mathrm{N}$ concentration by a combustion method (Sweeney 1989), using an Elementar RapidN analyser (Elementar analysensysteme GmbH: Germany). NDIN and ADIN concentrations were determined on the residue of the extrusa samples by analysis for fibre and then N. Ash-free neutral detergent fibre and ash-free acid detergent fibre were determined using the Fibretec 2021 Fibrecap system developed by Foss Tecator (Foss Tecator 2002a, 2002b). In vitro organic matter digestibility (IVOMD) was determined on extrusa samples using a two-stage technique (Tilley and Terry 1963), as modified by Minson and McLeod (1972). Rumen fluid was collected from a rumen-fistulated steer grazing tropical grass pasture (non-standard diet). The IVOMD of RG extrusa was determined using the pepsin-cellulase technique, based on methods of McLeod and Minson (1978) and McLeod and Minson (1980). For both methods, the IVOMD values were corrected by including standard pasture samples of known in vivo digestibility in the assays. The concentrations of VFA present in rumen fluid samples were determined by gas chromatography, using a polar capillary column (DB-FFAP), after initial protein precipitation with metaphosphoric acid. Prior to determination of rumen ammonia- $\mathrm{N}$ concentration, rumen fluid was shaken and then centrifuged ( $2600 \mathrm{~g}$ for $12 \mathrm{~min}$ ) to obtain a clear supernatant. After a reaction, which converts ammonia to form an indophenol dye (Bolleter et al. 1961), spectrophotometric determination was conducted on an Olympus AU400 clinical analyser. Digesta samples were analysed for $\mathrm{Yb}$ using a Varian 220FS Atomic Absorption Spectrometer with a nitrous oxide/acetylene flame and emission detection. The digesta samples were prepared for 
analysis by ashing $\left(500^{\circ} \mathrm{C}\right.$ for $\left.8 \mathrm{~h}\right)$ in a muffle furnace, followed by an acid digest using nitric and hydrochloric acids and potassium chloride. The acid digests were centrifuged (1100g for $10 \mathrm{~min}$ ) before analysis. Background matrices in digesta were measured in spot samples taken for each steer immediately before commencement of $\mathrm{Yb}$ dosing, and these were used in standard curve preparation for $\mathrm{Yb}$ analysis.

\section{Calculations}

The equation described by Broderick (1994) and based on the original work of Ørskov and McDonald (1979) was used to estimate the concentration of rumen undegradable dietary protein (UDP, $\mathrm{g} / \mathrm{kg} \mathrm{DM}$ ) in extrusa samples:

$$
\begin{aligned}
\mathrm{UDP}(\mathrm{g} / \mathrm{kg} \mathrm{DM})= & B(\mathrm{~g} / \mathrm{kg} \mathrm{DM}) \times k_{p}(/ \mathrm{h}) \\
& /\left[k_{p}(/ \mathrm{h})+k_{d}(/ \mathrm{h})\right]+C(\mathrm{~g} / \mathrm{kg} \mathrm{DM})
\end{aligned}
$$

where $B$ is the potentially degradable fraction of UDP (NDIN-ADIN in unincubated extrusa $\times 6.25$ ), $C$ is the undegradable fraction (ADIN in unincubated extrusa $\times 6.25$ ), $k_{p}$ is the rumen particulate matter FOR (calculated as described below or using an assumed value of $0.02 / \mathrm{h} ;$ CSIRO 2007), and $k_{d}$ is the hourly rate of degradation of fraction $B$. The effective UDP and rumen degradable protein concentrations as a proportion of total extrusa crude protein $(\mathrm{CP})$ were then determined according to the following equations:

$$
\begin{gathered}
\mathrm{UDP}(\mathrm{g} / \mathrm{g} \mathrm{CP})=\mathrm{UDP}(\mathrm{g} / \mathrm{kg} \mathrm{DM}) / \mathrm{CP}(\mathrm{g} / \mathrm{kg} \mathrm{DM}) \\
\operatorname{Edg}(\mathrm{g} / \mathrm{g} \mathrm{CP})=1-\mathrm{UDP}(\mathrm{g} / \mathrm{kg} \mathrm{CP})
\end{gathered}
$$

The FOR of $\mathrm{Yb}$ in rumen digesta $\left(k_{p}\right)$ was determined by regressing the natural $\log (\ln )$ of $\mathrm{Yb}$ concentration against time, with the rate constant $k$ determined as the slope of the regression so that FOR $(/ h)=-k$.

The disappearance of $\mathrm{OM}(\mathrm{g} / \mathrm{kg})$ from nylon bags was plotted against time, using the statistical package GENSTAT for Windows (6th edition; GENSTAT Committee 2000) and the model described by McDonald (1981), where $Y_{1}=A$ up to time $\mathrm{t}_{0}$, and $Y_{2}=a+b$ $\left(1-\mathrm{e}^{-c t}\right)$, from time $\mathrm{t}_{0}$ onwards. In these equations, $A$ is the measured washing loss from control nylon bags $(\mathrm{g} / \mathrm{kg}), a$ is the rapidly degraded fraction $(\mathrm{g} / \mathrm{kg}), b$ is the more slowly degraded fraction $(\mathrm{g} / \mathrm{kg}), a+b$ represents the potential degradable fraction $(\mathrm{g} / \mathrm{kg}), c$ is the degradation rate $(/ \mathrm{h})$ of $b$, and $\mathrm{t}_{0}$ is the lag time $(\mathrm{h})$ before the commencement of degradation of $b$, calculated from the fitted equation as the value of $\mathrm{t}$ when $Y=A$.

\section{Statistical analyses}

As the grazing studies were conducted sequentially, in different paddocks and at different times of the year, according to pasture availability and rainfall, it was not appropriate to make statistical comparisons between the pasture treatments for extrusa characteristics or rumen parameters. Genstat for Windows (6th edition; Genstat Committee 2000) was used to conduct parallel curve analysis to compare the exponential pattern of nylon bag OM disappearance for the seven extrusa types. The experimental unit was the steer. The form of the exponential used was $Y=S+Q R^{\mathrm{t}}$, where $Y$ is the $\mathrm{OM}$ disappearance $(\mathrm{g} / \mathrm{kg}), S$ is the constant parameter, $Q$ is the linear parameter, $R$ is the curvature parameter, and $t$ represents time (h). The results of the tests of statistical difference between coefficients are presented in the form of the coefficients of the equation $Y=a+b\left(1-\mathrm{e}^{-c t}\right)$, with the significance of testing $Q$ being applicable to $b$ (slowly degradable fraction), the significance of testing $S$ being applicable to $a+b$ (potential degradable fraction), and the significance of testing $R$ being applicable to $c$ (degradation rate). Where there were significant differences $(P<0.05)$ between coefficients, approximate pairwise comparisons between pastures were made using a protected 1.s.d. procedure $(P=0.05)$.

\section{Results}

The extrusa composition and rumen parameters for the seven pasture types are given in Table 1. The extrusa collected from the pastures varied widely in CP content and IVOMD. Tropical grass pastures (NPEW, NPT, NPD and BB) had much lower CP content than for tropical legumes (LL and BP) and RG. Steers grazing the two tropical legumes (LL and BP) and RG had high rumen ammonia-N concentrations compared with those grazing the tropical grass pastures. Branched-chain fatty acid (BCFA) concentrations and molar proportions in the rumen fluid were very low in steers grazing tropical grass pastures and much lower than values for steers grazing LL, BP and RG pastures. Steers

\begin{tabular}{|c|c|c|c|c|c|c|c|}
\hline & \multicolumn{4}{|c|}{ Tropical grass } & \multicolumn{2}{|c|}{ Tropical legume } & \multirow{2}{*}{$\begin{array}{c}\text { Temperate grass } \\
\text { RG }\end{array}$} \\
\hline & NPEW & NPT & NPD & $\mathrm{BB}$ & LL & $\mathrm{BP}$ & \\
\hline \multicolumn{8}{|c|}{ Extrusa } \\
\hline $\mathrm{CP}(\mathrm{g} / \mathrm{kg} \mathrm{DM})$ & 76 & 38 & 28 & 59 & 250 & 131 & 363 \\
\hline IVOMD (g/kg) & $681 \pm 1.4$ & $656 \pm 10.5$ & $608 \pm 4.4$ & $724 \pm 1.0$ & $777 \pm 7.1$ & $585 \pm 8.8$ & $827 \pm 0.5$ \\
\hline \multicolumn{8}{|c|}{ Rumen parameters } \\
\hline Ammonia-N (mg/L) & $17.0 \pm 1.37$ & $8.0 \pm 0.59$ & $22.5 \pm 3.74$ & $16.7 \pm 1.64$ & $378.0 \pm 10.20$ & $182.4 \pm 6.52$ & $382.3 \pm 7.56$ \\
\hline $\begin{array}{l}\text { Total VFA concentration } \\
\quad(\mathrm{mmol} / \mathrm{L})\end{array}$ & $23.0 \pm 1.13$ & $80.8 \pm 4.54$ & $67.5 \pm 2.26$ & $30.5 \pm 1.91$ & $169.6 \pm 6.94$ & $129.2 \pm 4.09$ & $99.6 \pm 2.47$ \\
\hline $\begin{array}{l}\text { Molar proportion of BCFA } \\
(\% \text { of total })^{\mathrm{A}}\end{array}$ & 1.3 & 0.9 & 1.4 & 1.1 & 4.1 & 3.8 & 7.1 \\
\hline Particle FOR $\left(k_{p} ; / \mathrm{h}\right)$ & $0.043 \pm 0.0028$ & $0.030 \pm 0.0014$ & $0.020 \pm 0.0015$ & $0.044 \pm 0.0024$ & $0.044 \pm 0.0052$ & $0.028 \pm 0.0025$ & $0.029 \pm 0.0027$ \\
\hline
\end{tabular}

Table 1. Composition of extrusa and key rumen parameters for steers grazing six tropical pastures and ryegrass

BCFA, branched-chain fatty acids; CP, crude protein; DM, dry matter; FOR, fractional outflow rate; IVOMD, in vitro organic matter digestibility; N, nitrogen; VFA, volatile fatty acid. Treatment descriptions are given in the text; results are presented as mean \pm s.e.

\footnotetext{
${ }^{\mathrm{A}} \mathrm{Sum}$ of isobutyrate and isovalerate.
} 
grazing early to mid wet season $\mathrm{C}_{4}$ pastures (NPEW and $\mathrm{BB}$ ) had high particle FOR, similar to those for LL and higher than those for RG and BP. However, particle FOR for steers grazing mature native $\mathrm{C}_{4}$ grass pasture (NPD) was very low.

Table 2 summarises the degradability parameters for extrusa incubated in nylon bags in the rumen of RF steers. Statistical tests showed significant $(P<0.001)$ differences in slowly degraded OM fractions $(b)$, potential degradable OM fractions $(a+b)$ and degradation rates of $\mathrm{OM}(c)$ between the seven pasture types. The potential degradable fraction of RG and LL extrusa OM was greater $(P<0.05)$, and of BP and NPD extrusa lower $(P<0.05)$, than for other pastures. The degradation rate of LL extrusa was higher $(P<0.05)$ than that of $\mathrm{RG}$, but these far exceeded values for all other pasture types. The lowest $(P<0.05)$ degradation rate was for NPD.

The Edg, estimated using measured $k_{p}$ values, was high for both $\mathrm{C}_{4}$ and $\mathrm{C}_{3}$ pasture species, approaching $0.90 \mathrm{~g} / \mathrm{g} \mathrm{CP}$ on average for early to mid wet season tropical grass pastures (NPEW and BB) and ranging from 0.95-0.98 g/g CP for $\mathrm{C}_{3}$ species. The effective UDP fraction of extrusa DM was low for all forages and varied little between $\mathrm{C}_{3}$ and $\mathrm{C}_{4}$ species. However, the ERDP fraction of extrusa DM for tropical $\mathrm{C}_{4}$ grass pastures was much lower than for the $\mathrm{C}_{3}$ species. Edg, ERDP and UDP estimates made using the assumed $k_{p}$ value of $0.02 / \mathrm{h}$ gave very similar values to those when the measured $k_{p}$ values were used.

\section{Discussion}

Estimated Edg values were high for both $\mathrm{C}_{4}(0.82-0.91 \mathrm{~g} / \mathrm{g} \mathrm{CP})$ and $\mathrm{C}_{3}(0.95-0.98 \mathrm{~g} / \mathrm{g} \mathrm{CP})$ forages. The high Edg values obtained for the tropical legumes and RG were in keeping with their high $\mathrm{CP}$ content and generally high IVOMD and in sacco OM degradability, and were reflected in the high concentrations of ammonia-N and BCFA in rumen fluid. Such high Edg values have been reported previously for ryegrass varieties (e.g. González et al. 2007). However, there are few reported Edg values for tropical forages of low $\mathrm{CP}$ content with which to compare our measurements. Most published values for protein degradation in low to moderate quality forages probably underestimate Edg, due to inadequate allowance for microbial colonisation of the bag residue (e.g. Dixon and Chanchai 2000). This was overcome in our study by using the procedure developed by Mass et al. (1999) and Klopfenstein et al. (2001), which measures the disappearance of NDIN from incubated material where any microbial material would be removed in the fibre digestion phase. ADIN was used to indicate the undegradable fraction of UDP $(C)$ as recommended in the UK Metabolisable Protein System (Waters et al. 1992; Webster 1992) and the Cornell Net Carbohydrate and Protein system (Sniffen et al. 1992). Based on the work of Mass et al. (1999), CSIRO (2007) recommend that the NDIN technique be used to estimate Edg for all forages with IVDMD $<700 \mathrm{~g} / \mathrm{kg}$. In our experiment, four out of six tropical forages studied had IVOMD $<700 \mathrm{~g} / \mathrm{kg}$. Furthermore, all four tropical grass pastures studied had very low $\mathrm{CP}$, with even early wet season pasture having $\mathrm{CP}<80 \mathrm{~g} / \mathrm{kg}$ DM. The values for Edg measured in our experiment are much higher than values predicted from some earlier equations (SCA 1990), exceeding $0.80 \mathrm{~g} / \mathrm{g}$ CP even for dry season, native $\mathrm{C}_{4}$ grass pastures.

A further limitation of using the in sacco approach to calculate Edg has been the need to either assume or measure rumen particle FOR. Particle FOR estimated in cattle grazing the pastures in this study covered a wide range, from $0.020-0.044 / \mathrm{h}$. These data are interesting in themselves because there are few such values in the literature, although in this case they should be regarded as relative rather than absolute as the dilution rate studies were conducted under non-steady-state conditions. Owing to the difficulties presented in measuring $k_{p}$ under

Table 2. Degradability parameters for extrusa collected from oesophageal-fistulated steers while grazing each of seven pasture types and then incubated in sacco in rumen-fistulated steers consuming a standard diet

Fitted equations are given in the text. The parameters are: $a$, rapidly degradable fraction; $b$, more slowly degraded fraction; $a+b$, potential degradable fraction; and $c$, degradation rate of $b . \mathrm{CP}$, crude protein; DM, dry matter; Edg, effective degradability of protein; ERDP, effective rumen degradable protein fraction; $k_{p}$, rumen particulate matter fractional outflow rate; OM, organic matter; UDP, rumen undegradable protein fraction. Treatments are defined in the text. Results $(m e a n \pm$ s.e.) are for three steers. Residual standard deviation (r.s.d.) of the fitted equation is presented. Within rows, values followed by different letters are significantly different at $P=0.05$

\begin{tabular}{|c|c|c|c|c|c|c|c|c|}
\hline & \multicolumn{4}{|c|}{ Tropical grass } & \multicolumn{2}{|c|}{ Tropical legume } & \multirow{2}{*}{$\begin{array}{c}\text { Temperate grass } \\
\text { RG }\end{array}$} & \multirow{2}{*}{$P$-value } \\
\hline & NPEW & NPT & NPD & $\mathrm{BB}$ & LL & $\mathrm{BP}$ & & \\
\hline \multicolumn{9}{|c|}{ Degradability of $O M$} \\
\hline$a(\mathrm{~g} / \mathrm{kg} \mathrm{OM})$ & $34 \pm 12.5$ & $104 \pm 12.8$ & $61 \pm 7.7$ & $176 \pm 14.5$ & $52 \pm 92.3$ & $353 \pm 19.5$ & $100 \pm 56.3$ & N/A \\
\hline$b(\mathrm{~g} / \mathrm{kg} \mathrm{OM})$ & $781 \mathrm{a} \pm 12.2$ & $719 b \pm 12.7$ & $691 b \pm 7.5$ & $620 \mathrm{c} \pm 14.1$ & $821 \mathrm{ab} \pm 89.6$ & $374 d \pm 19.2$ & $859 \mathrm{a} \pm 54.0$ & $<0.001$ \\
\hline$a+b(\mathrm{~g} / \mathrm{kg} \mathrm{OM})$ & $815 \mathrm{bc}$ & $823 b$ & $752 \mathrm{~d}$ & $796 c$ & $873 a$ & $727 \mathrm{~d}$ & $959 \mathrm{a}$ & $<0.001$ \\
\hline$c(/ \mathrm{h})$ & $0.079 \mathrm{c} \pm 0.0024$ & $0.060 \mathrm{~d} \pm 0.0025$ & $0.047 \mathrm{e} \pm 0.0014$ & $0.078 \mathrm{c} \pm 0.0034$ & $0.280 \mathrm{a} \pm 0.0311$ & $0.077 \mathrm{c} \pm 0.0079$ & $0.225 b \pm 0.0167$ & $<0.001$ \\
\hline r.s.d. & 14.5 & 18.1 & 11.6 & 16.8 & 28.4 & 24.0 & 24.8 & \\
\hline \multicolumn{9}{|c|}{ Effective degradability of protein } \\
\hline $\begin{array}{l}\text { At measured } k_{p} \\
E d g(g / g C P)\end{array}$ & 086 & 0.83 & 082 & & & & 0.98 & \\
\hline $\begin{array}{l}\operatorname{Edg}(\mathrm{g} / \mathrm{g} D P(\mathrm{~g} / \mathrm{kg} \mathrm{DM}) \\
\text { ERD }\end{array}$ & $\begin{array}{r}0.86 \\
66\end{array}$ & $\begin{array}{r}0.83 \\
31\end{array}$ & $\begin{array}{r}0.82 \\
23\end{array}$ & $\begin{array}{r}0.91 \\
54\end{array}$ & $\begin{array}{l}0.97 \\
243\end{array}$ & $\begin{array}{r}0.95 \\
124\end{array}$ & $\begin{array}{r}0.98 \\
356\end{array}$ & \\
\hline $\mathrm{UDP}(\mathrm{g} / \mathrm{kg} \mathrm{DM})$ & 10 & 6 & 5 & 6 & 7 & 7 & 6 & \\
\hline \multicolumn{9}{|l|}{ At $k_{p}=0.02 / \mathrm{h}$} \\
\hline Edg (g/g CP) & 0.90 & 0.85 & 0.82 & 0.94 & 0.98 & 0.95 & 0.99 & \\
\hline ERDP (g/kg DM) & 69 & 32 & 23 & 56 & 244 & 124 & 357 & \\
\hline UDP (g/kg DM) & 7 & 6 & 5 & 4 & 6 & 7 & 5 & \\
\hline
\end{tabular}


grazing conditions, most workers use assumed $k_{p}$ values such as those proposed by ARC (1984) and endorsed by CSIRO (2007). Our results indicate that Edg is not highly sensitive to $k_{p}$ across the range of species studied, meaning that the assumed $k_{p}$ values, e.g. $0.02 / \mathrm{h}$ for tropical forages, will provide a reasonable estimate of Edg.

$\mathrm{C}_{4}$ tropical grasses had much lower ERDP fractions (23-66 g/kg DM) than the $\mathrm{C}_{3}$ pasture species RG and LL (356 and $243 \mathrm{~g} / \mathrm{kg} \mathrm{DM}$, respectively). This was associated with lower potential degradability and degradation rate of $\mathrm{OM}$ in sacco, lower IVOMD and CP concentrations in extrusa and with lower ammonia-N and BCFA concentrations in rumen fluid. There was much less variation in the effective UDP fraction between forages $(5-10 \mathrm{~g} / \mathrm{kg} \mathrm{DM})$ and values were low for all grazed forages, regardless of species type or maturity. As tropical grass pastures senesced, there was a decline in Edg, the ERDP and UDP fractions, potential degradability and degradation rate of $\mathrm{OM}$ and the IVOMD of the extrusa. The values obtained in our experiment for potential degradability and degradation rate of OM in extrusa samples were higher than those obtained by others for both tropical $\mathrm{C}_{4}$ grass hays and ryegrass hay (Hunter and Siebert 1985; Panjaitan et al. 2006). This probably reflects the higher quality of plant material selected by grazing cattle compared with that in the total pasture on offer.

In conclusion, the values reported here provide quantitative estimates for Edg and ERDP for a wide range of tropical forage types not previously documented. These values can now be used by other workers to assess adequacy of $\mathrm{N}$ supply to microbes for ruminants grazing tropical pastures and the likely effects on animal productivity.

\section{Acknowledgements}

This study was mainly funded by the Department of Primary Industries and Fisheries, Queensland (DPI\&F), who provided postgraduate support for M. K. Bowen. M. K. Bowen was also in receipt of an Australian Government Postgraduate Research Award. We are grateful to the Health and Nutritional Biochemistry Laboratory of DPI\&F for conducting laboratory analyses and to Vivienne Doogan for assistance with statistical analyses. We also thank the staff of Brian Pastures Research Station, Gayndah for providing assistance with field work.

\section{References}

ARC (1984) Report of the Protein Group of the Agricultural Research Council Working Party on the Nutrient Requirements of Ruminants. Commonwealth Agricultural Bureaux, Farnham Royal, UK.

Bolleter WT, Bushman CF, Tidwell PW (1961) Spectrophotometric determination of ammonia as indophenol. Analytical Chemistry 33, 592. doi: $10.1021 / \mathrm{ac} 60172 \mathrm{a} 034$

Broderick GA (1994) Quantifying forage protein quality. In 'National conference on forage quality, evaluation and utilization'. (Eds GC Fahey, M Collins, DR Mertens, LE Moser) pp. 200-228. (University of Nebraska: Lincoln, WL)

CSIRO (2007) 'Nutrient requirements of domesticated ruminants.' (Eds M Freer, H Dove, J Nolan ) (CSIRO Publishing: Collingwood, Vic.)

Dixon RM, Chanchai S (2000) Colonization and source of N substrates used by microorganisms digesting forages incubated in synthetic fibre bags in the rumen. Animal Feed Science and Technology 83, 261-272. doi: 10.1016/S0377-8401(99)00128-5

Foss Tecator (2002a) 'Application sub-note ASN 3805. The determination of neutral detergent fibre using the Fibercap system.' (Foss Tecator: Hoganas, Sweden)
Foss Tecator (2002b) 'Application sub-note ASN 3804. The determination of acid detergent fibre using the Fibercap system.' (Foss Tecator: Hoganas, Sweden)

Genstat Committee (2000) 'The guide to Genstat. Part 2: statistics.' (VSN International Ltd: Oxford, UK)

González J, Faría-Mármol J, Rodríguez CA, Martínez A (2007) Effects of ensiling on ruminal degradability and intestinal digestibility of Italian rye-grass. Animal Feed Science and Technology 136, 38-50. doi: 10.1016/j.anifeedsci.2006.08.022

Hunter RA, Siebert BD (1985) Utilization of low-quality roughage by Bos taurus and Bos indicus cattle. 1. Rumen digestion. The British Journal of Nutrition 53, 637-648. doi: 10.1079/BJN19850073

Klopfenstein TJ, Mass RA, Creighton KW, Patterson HH (2001) Estimating forage protein degradation in the rumen. Journal of Animal Science 79, E208-E217.

Mass RA, Lardy GP, Grant RJ, Klopfenstein TJ (1999) In situ neutral detergent insoluble nitrogen as a method for measuring forage protein degradability. Journal of Animal Science 77, 1565-1571.

McDonald I (1981) Short Note. A revised model for the estimation of protein degradability in the rumen. Journal of Agricultural Science, Cambridge 96, 251-252.

McLeod MN, Minson DJ (1978) The accuracy of the pepsin-cellulase technique for estimating the dry matter digestibility in vivo of grasses and legumes. Animal Feed Science and Technology 3, 277-287. doi: 10.1016/0377-8401(78)90002-0

McLeod MN, Minson DJ (1980) A note on Onozuka 3S cellulose as a replacement for Onuzuka SS (P1500) cellulose when estimating forage digestibility in vitro. Animal Feed Science and Technology 5, 347-350. doi: 10.1016/0377-8401(80)90022-X

Minson DJ, McLeod MN (1972) The in vitro technique: its modification for estimating digestibility of large numbers of tropical pasture samples. Division of Tropical Pastures, Technical Paper No. 8.

Ørskov ER, McDonald I (1979) The estimation of protein degradability in the rumen from incubation measurements weighted according to rage of passage. Journal of Agricultural Science, Cambridge 92, 499-503.

Panjaitan TS, McLennan SR, Doogan VJ, Poppi DP (2006) Effect of various rumen degradable protein sources on the rate of fibre digestion of various forages in cattle consuming speargrass hay. Proceedings of the Australian Society of Animal Production 26, Short Communication 83.

SCA (1990) 'Feeding standards for Australian livestock. Ruminants.' (CSIRO Publishing: East Melbourne, Vic.)

Sniffen CJ, O'Connor JD, Van Soest PJ, Fox DG, Russell JB (1992) A net carbohydrate and protein system for evaluating cattle diets. II. Carbohydrate and protein availability. Journal of Animal Science 70, 3562-3577.

Stobbs TH (1975) Factors limiting the nutritional value of grazed tropical pasture for beef and milk production. Tropical Grasslands 9, 141-150.

Sweeney RA (1989) Generic combustion method for determination of crude protein in feeds. Journal - Association of Official Analytical Chemists $\mathbf{7 2}$, 770-774.

Tilley JMA, Terry RA (1963) A two-stage technique for the in vitro digestion of forage crops. Journal of British Grasslands Society 18, 104-111.

Waters CJ, Kitcherside MA, Webster AJF (1992) Problems associated with estimating the digestibility of undegraded dietary nitrogen from aciddetergent insoluble nitrogen. Animal Feed Science and Technology 39, 279-291. doi: 10.1016/0377-8401(92)90047-A

Webster AJF (1992) The metabolisable protein system for ruminants. In 'Recent advances in animal nutrition 1992'. (Eds P Garnsworthy, DJA Cole) pp. 93-110. (Butterworth-Heinemann Ltd: London)

Manuscript received 18 December 2007, accepted 6 March 2008 